\title{
Covid-19 e museus: sintomas versus evidências
}

Covid-19 y museo: sintomas versus evidence

Covid-19 and museum: symptoms versus evidence

Maria Cecília França Lourenço

Professora Titular Sênior FAU USP, São Paulo, SP, Brasil. mcfloure@usp.br 


\title{
Resumo
}

O texto visa inquirir sobre intervenções online em obras museais, na pandemia, advinda da atual Síndrome. Criações icônicas foram espelhadas, mas também relidas. Debate-se: museus nutririam os elos com o público ao voltar ao normal? A ação se abrirá a outros? Por que se optou por tais criações e órgãos? Seria sintoma de atributo raro, ou o renome se originou de marketing? Teria a crise suscitado diálogo com museu, em forma de lazer? Vivificou-se o papel de bem cultural?

Palavras-Chave: Museu. Intervenção. Pandemia. Vestígio. Público.

\section{Resumen}

El texto pretende preguntar sobre las intervenciones en línea en obras museales, en la pandemia, procedentes del Síndrome actual. Las creaciones icónicas se han reflejado, pero también se han releído. Debate: ¿fomentarían los museos vínculos con el público cuando vuelvan a la normalidad? ¿La acción se abrirá a los demás? ¿Por qué se han elegido tales creaciones y órganos? ¿Sería un síntoma de atributo raro, o el cambio de nombre se originó en marketing? ¿Habría levantado la crisis el diálogo con un museo en forma de ocio? ¿Se ha animado el papel del bien cultural?

Palabras clave: Museo. Intervención. Pandemia. Rastro. Público.

\begin{abstract}
The theme aims to inquire about actions and experiments in museums and/or images, expressed, in the pandemic. This was attracted by both, facilitated by dissemination of these on a worldwide scale. Debate: would they end, would they nurture links with such an audience? Will the appeal to humour and theatricality give rise to critical reflections with the triggered content? Why did they choose such images and museums? Would it be a desire to dialogue with others, leisure and distraction or fascination for times and past ages?
\end{abstract}

Keywords: Museum. Intervention. Pandemic. Trace. Public 


\section{INTRODUÇÃO}

"Pelas Musas heliconíades comecemos a cantar. Elas têm grande e divino monte Hélicon, em volta da fonte violácea com pés suaves dançam e do altar do bem forte filho de Crono". (HESÍODO, 1995, p.87).

\footnotetext{
A OMS (Organização Mundial de Saúde) declarou estar em curso surto de SARSCoV-2 (Síndrome Respiratória Aguda Grave de Coronavírus), nomeada por Covid-19, em escala mundial, a tipificar estado pandêmico, em 11 de março de 2020 e recomendou isolamento social, derivando em fechamento de museus ${ }^{1}$. Mesmo os que incorporam denso capital simbólico e financeiro, de imediato atenderam ${ }^{2}$ e, pior,
}

\footnotetext{
${ }^{1}$ A pesquisa compõe o Projeto Professor Sênior na FAU USP junto ao Grupo Museu/Patrimônio FAU USP, que lidero. Iniciei-a em agosto de 2020, sob o título "Intra museus: acesso liberado".

${ }^{2}$ Como se veiculou no país, governos estaduais decretaram fim de ações em presença para público e afastamento social para funcionários com risco, a incluir em museus. Fecharam em SP (16.03), MG
} 
dispensaram pessoal, além de romper contratos, fato veiculado em várias mídias e evidência da hierarquia interna ${ }^{3}$. Sintoma decisivo dessa condição emerge de que alterações se deram até mesmo entre os que exibem instalação glamurosa e sediam megaexposições, ditas blockbusters, já que estas pesam para todos os níveis laborais de seu quadro funcional, muitos destes, dispensados.

Agravante de igual magnitude decorre do modelo de gestão terceirizado, por meio de vários tipos de organização, o que pode facilitar a precarização de fazeres essenciais. $O$ pretenso sucesso do padrão decorreu de recursos que na pandemia escancaram a fragilidade, sem a menor chance de sobreviver. Entre estes, estão: marketing agressivo; seleção de obras e poéticas afeitas a show midiático; divulgação de colossais filas na bilheteria; merchandising em telas diversas; curadores na mídia, tudo isto a custo não confesso e inimaginável para especialistas, lá operando. Ademais, acolhem colecionadores de obras semelhantes, em seu Conselho, estratégia para valorizá-las, mas não apenas na esfera artística.

Ante tantos interditos, inquire-se: como a imagem institucional, própria ou de objetos museais se tornou o núcleo de atos, desde os ligados a catástrofes e desastres, até os nascidos na atual pandemia? Sem estratégias mercantis alcançariam distantes fronteiras? Relembro algumas situações trágicas, perpassadas por visualidade atrativa, para se refletir sobre tal encanto, nesta hora de isolamento social, este restrito aos que podem vivenciá-lo. O sentido etimológico de museu origina-se na Antiguidade grega como a casa das musas, consagrado na "Teogonia" do poeta Hesíodo. O mito relativo às Musas aduz à sua função em conduzir pessoas públicas no bom caminho e assim desviá-las de prováveis desacertos, algo sintomático e sempre oportuno. Embora em finalidades e atuações bem distintas, o

(18.03); RJ e BA (19.03); PR (20.03) ES e PE (21.03). O mesmo em: Lisboa (10.03); Viena (11.)3); nos espanhóis (11.03; os de Nova lorque/EUA (12.03); Louvre (13.03); as várias instituições da Tate (16.03).

${ }^{3}$ Jornais noticiaram que o Instituto Inhotim em Brumadinho/MG demitiu, entre maio e junho, 84 funcionários, ainda assim, restaram 351. Destes 139 seriam manutenção do parque e galerias e os demais ficaram em trabalho remoto. O MASP anunciou corte de 21 pessoas e declarou em "Nota Oficial", para além de suporte empresarial, por renúncia fiscal, que envidaram esforços para reduzir despesas para "[...] manter a saúde financeira e operacional da instituição". Quanto às operações para obter capital arrolam "[...] ingressos, restaurante, lojas e locação de espaços para eventos e espetáculos \{...]." 
museu coleciona como outros e compõe instituição de longa duração, assinale-se, nem sempre aberto de forma irrestrita para o acesso ${ }^{4}$, o que se mantém, pois há convidados ditos vips, cujo foco é apenas atrair fundo financeiro.

A finalidade de obras como ativo simbólico, há muito se opera e na Era Medieval, várias religiões acolheram majestosas obras e coleções. Sob a capa de mecenas, estas práticas foram usuais como forma de espelhar a própria força, unidade e doutrina. Afinal, visavam conteúdo dogmático, fixado em vitral, escultura, pintura, templo, relicário, som, túmulo e narrativas, para os que não sabiam ler, a imensa maioria. Santos mitificados e traidores odiados provocaram, de um lado, visão de glória, harmonia, paz; de outro, viés apocalíptico, império de pavor, dor e agonia, ante o fim trágico de pecantes, nas labaredas do inferno. Tanto colecionismo, quanto cuidados na escolha adequada de motivos, artistas e visualidade emergiram para ungir adesão à religião via sentidos, sem poupar roubo e violência.

Ademais, imagens como atributo de poder e símbolos colecionáveis aparecem em governos vários, não importa se religiosos, monárquicos, ditatoriais, democráticos ou guerreiros. Após luta, espoliam-se partes inteiras de templos, a fim de exibi-las na condição de troféu saqueado de vencidos. Essa habitual apropriação mira fortalecer dado conceito sobre o poder para súditos, fiéis e conterrâneos. No entanto, sofreu um choque colossal na Revolução Francesa (1789), porquanto, em nome de Liberdade, Igualdade e Fraternidade, raiou forte reação a pretender destruir a coleção real, após dizimar seus túmulos. As obras foram salvas por ativismo de pensadores. Alegavam que, em vez de aniquilá-las, melhor seria referenciá-las no tempo e espaço, via novos arranjos, dispostos ao olhar ${ }^{5}$, lição a se pensar nesta ocasião.

\footnotetext{
${ }^{4}$ Observe-se as coleções papais no Vaticano, que, apenas após a Reforma Luterana no Século XVI, a Igreja Católica iniciou lenta permissão à visitação e em dada época. Urgia reverter a perda de fiéis e ganhos, por meio de dízimo, venda de indulgência, cessão de bens, para citar fatores declarados por rebelados contra essa ação.

${ }^{5}$ A restrição inicial para ingresso no Museu do Louvre Paris/FRA, somente facilitada a artistas, talvez como garantia, tanto da função educacional, quanto técnica, temática, espacial dos antecessores, fins até hoje buscados.
} 
Aos embates some-se o advindo do Covid-19 em 2020, com a maioria das instituições fechadas sem poder levar a público obras, mostras, oficinas, palestras, cursos, coleções e agenda cultural, assim demudando a rotina de especialistas e colocando em xeque o processo preservacionista, atuante no bastidor. Quem e como continuaria o processo museal para salvaguarda, documentação, conservação, restauro, investigação, proposição de novas relações, extroversão qualificada para visitante, em distinta faixa etária ou sociais, além da própria integridade material e física da coleção?

Fulcral hoje sair da cena para os bastidores museais em esforço reflexivo sobre museus e a explosão de imagens geradas nas mídias digitais, lazer para crianças e adultos, busca de identidade, distante da restrição social. O interdito gerou frestas, frinchas, rasgaduras e uso do que museus tinham à mão, em filmes, transmissão ao vivo, ou ditas lives, com curadores sobre obras e exposições, ateliês, podcasts e visita virtual para os que antes obtiveram recursos e operacionalidade digitais. No geral, pouco se ousou em novos fazeres. O que emergiu foram défices e esforço legítimo para não perder vínculo com espectadores e interessados.

Como então garantir interesse nos carentes em apoio, recursos digitais e orçamentários, havendo para estes demandas prementes em andamento, entre tantas, programas expositivos, alteração na museografia para variados segmentos, articulação entre equipes em atividade multidisciplinar, projeto educacional em visitas presenciais, processo preservacionista, a par de patrocínio para complemento do que faltava? Pessoas criativas e dirigentes abertos colaboraram com variadas reações para essa crise e muitos, realce-se, não desligaram pessoal, como os universitários $^{6}$. Alguns, entre museus-celebridade, informaram intenção em acolher coleções em mídia digital, compostas por objetos prosaicos da pandemia, como o

\footnotetext{
${ }^{6}$ Segundo a Veja, em 4 de maio de 2020, museus paulistanos - Afro, de Arte Sacra e da Casa Brasileira demitiram.
} 
inglês Victoria \& Albert $^{7}$. Igualmente, mas dotados de propósitos bem diversos, museus criaram situações interativas e menos óbvias.

Experiência diferenciada na recolha de coleções ocorreu no Museu das Coisas Banais/ Universidade Federal de Pelotas/RS, que funciona em ambiente virtual, tendo proposto acolher objetos ligados à lembrança de pessoas distantes ante o isolamento, ressaltando assim valor afetivo ligado a ambos. Arquivos e bibliotecas também divulgaram coleta de testemunhos ${ }^{8}$. Lançaram-se desafios para selfies em que a tônica seria tanto recriar ou reproduzir clássicos de acervos museais com objetos caseiros, ou, acrescentá-los em obras famosas ${ }^{9}$. Aponte-se outra iniciativa relevante, a abordar a pandemia como questão de estado, cite-se a Itália com o Projeto - La cultura non si ferma (A cultura não se para), bem distinto de outros, como o nosso.

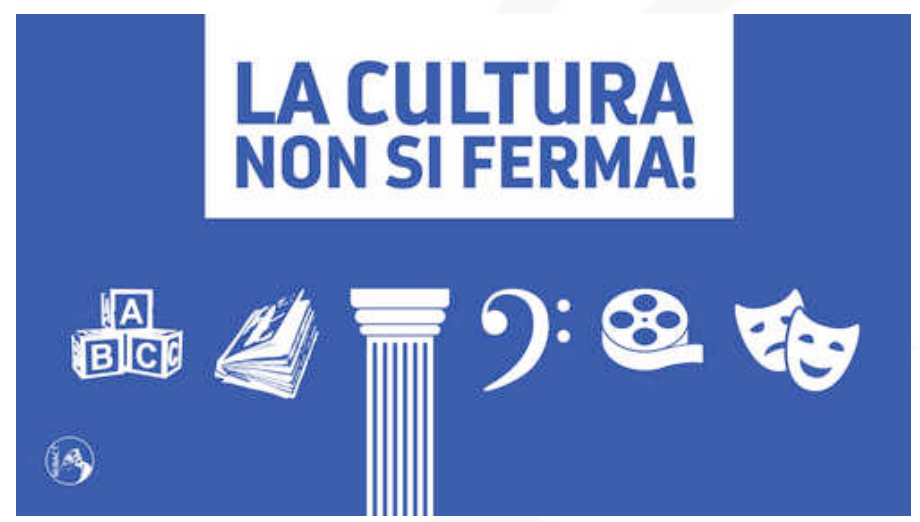

Figura 1:- La cultura non si ferma. Fonte: Disponível em: https://www.beniculturali.it/ Acesso em:23 de abr. de 2020

\footnotetext{
7 Informaram, logo no início da Covid-19, interesse em abrigar objetos prosaicos, máscaras, frascos higienizadores, contas causadas ela compra destes e pretendiam fazer depois uma exposição. No entanto, em setembro anunciaram outra mostra, bem diferente, Opera: Passion, Power and Politics, a abrir em 30.09.2020, na sede reformulada por concurso, vencido pela arquiteta Amanda Levete (1955), autora do Museu de Arte e Arquitetura de Lisboa.

${ }^{8}$ Arquivo Geral da Cidade do Rio de Janeiro lançou "Testemunhos do isolamento" com relatos, como se divulgou.

${ }^{9}$ Prontamente lançou-se em redes sociais o Museu Tussen Kunst, em \#tussenkunstenquarantaine em 14 de março; a seguir (25.03) no Twitter a encarregada pelo setor de mídias sociais do Museu J. Paul Getty em Los Angeles/EUA, divulgou, o perfil, \#betweenartandquarantine. O desafio girou em torno de recriar obras com objetos usuais da casa. Grupos logo se formaram como o russo \#izoizolyacia, registrado em 30 de março.
} 
Já no início brotaram no país posicionamentos imperativos e apropriados, como o do Conselho Internacional de Museus/ ICOM, em abril de 2020 - "Recomendações do ICOM Brasil em relação à Covid-19". Neste, assinado pela atenta e protagonista direção, junto com outros especialistas. Enfaticamente alertou-se sobre gestão na pandemia; com cuidados desde a integridade de funcionários, obras, aparelhos; premência na continuidade em tarefas para conservação, restauro e segurança nas instituições. Reflexões críticas apontaram em forma digital, em março, com especial produção nas universidades públicas ${ }^{10}$.

Outros apoiaram criar obras e, também, surgiram campanhas, como "Escolha Achatar a Curva", abraçada pela OMS e Unesco (Organização das Nações Unidas para Educação, Ciência e Cultura), ao final de março, visando reforçar cuidados pessoais.

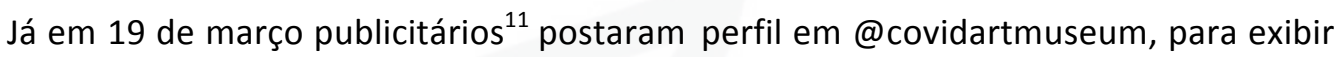
criações com alerta sobre o perigo, dando início ao Covid Art Museum, digital, embora arte seja mais do que mera ilustração. Museus pelo mundo se reinventaram, quando a OAS informou tratar-se de pandemia. Afinal, buscar soluções para problemas é algo usual no dia a dia do órgão.

Pensadores sempre revisitados, neste estudo voltam à cena, porquanto conceituam questões fundantes para este estudo. Introdutoriamente menciono Walter Benjamin, a refletir sobre o refluxo da aura, quando estas não se expõem diretamente ao público; Bruno Latour trouxe relações relativas à atração e ao choque de imagens; a estudiosa da ação iconoclasta desde as origens, abordando o extremo da morte de e pela imagem, com a consequente cisão entre oriente versus ocidente, Marie-José Mondzain; Jean Starobinski ao abordar as ruínas e o fascínio por estas; juntamente com a estudiosa, escritora e orientadora Aracy Abreu Amaral da FAU USP, por meio de competentes estudos ante a realidade brasileira.

\footnotetext{
${ }^{10}$ A colega e artista da FAU USP Giselle Beiguelman, desde março trouxe temas relevantes, em periódicos e magazine. Abordou, entre outras reflexões: sobre o espaço público; estéticas no confinamento em projeções urbanas; a volta da internet nos Anos 1990. Igualmente lançou, em junho, um livro questionando a biopolítica e vigilância, com bibliografia atualizada.

${ }^{11}$ Segundo se veiculou amplamente, trata-se de Emma Calvo, Irene Llorca e José Guerrero, situados na Espanha.
} 
Algumas hipóteses e análises estabelecem enfoques, em cada uma das três partes deste texto assim expressos: no tópico inicial, intitulado Ruínas e espetáculo, formulam-se aspectos, para se pensar como, por que e em que momento a hiperexposição imagética se tornou singular, trágica e latente? Sublinhe-se que neste século, ao contrário, dominam palavras, seja em forma de voz, escrita breve, por meio de mídias com amplo alcance, em suportes de grande extensão, como celulares; seja por inúmeras palavras diretivas e não raro falsas, disseminadas em redes, até aqui sem o menor balizamento crítico. Relembrarei os desastres e imediatas reações inaugurais e inquietantes recentes.

Interessa igualmente ponderar na parte seguinte, nomeada Atrações distintas por imagens, se o ardor por dado conjunto de criações, advém da condição de hiper reprodução, exibição, projeção e selfies nas redes sociais, a ponto de reduzir dado conjunto à condição de clichê e obra-prima? E mais, a antes conquistada visibilidade teria gerado disseminação ampla em mídias sociais e tradicionais? Residiria a paixão em proximidade cotidiana a museus e posts, a ponto de transformá-las em autoimagem? Se antes produção de valores se delegava a pintores, escultores, gravadores, entre outros, o que houve para se chegar a essa alteração? Seria a banalização e propagação reiterada, sucessivamente em fotografia, cinema e mais recentemente em tecnologias digitais? Continuariam na pós-pandemia?

Nas considerações explicitadas em Vestígios e ações invocam-se determinadas ações lúdicas, atitudes inovadoras e problematizações. Entre estas investigam-se: Quais as diferenças de atitudes proativas localizadas na pandemia para manter pessoal de museus e suas coleções? Garantiu-se condições material e inovadora para não interromper o diálogo entre público e instituição, ao menos em segmentos avizinhados, daqueles museus-conceito, para usar palavra banal no léxico mercantil? Ou, despontou cautela devida por responsáveis, a garantir suporte para enfrentar e 
aprimorar a continuidade? Observou-se alvorecer ou eclipse de apoio, daqueles que aderem a marca à cultura para dissimular graves danos na sociedade ${ }^{12}$ ?

\section{RUÍNAS EM ESPETÁCULO}

"Para que uma ruína pareça bela é preciso que a destruição seja bastante longínqua [...]. Ninguém sonha tranquilamente diante de ruínas recentes que fazem sentir o massacre: estas são logo desentulhadas para reconstruir"

(STAROBINSKI, 1994, p. 202).

Fendas vigorosas reviveram a intolerância extrema em tempos recentes, com armas inéditas, direcionadas a explodir o edificado pelo humano, fragmentá-lo, esclerosálo, como forma de aviltá-lo. Estas, neste século, laboraram como ritual nefasto contra ícones distintos e em confronto ético e ideológico. Lamentavelmente parece natural regredir-se e reviver barbáries anteriores, embora sempre se atualizam pretextos, foco e justificativas na cena político-religiosa. Ainda assim, ao se eleger inimigo externo para coesão interna, via promessas idílicas e ascensão ao paraíso, emergem subterrâneos do poder, a cada vez tentando dissimular intenções pessoais e de grupos por mando e riqueza material, agora em variadas telinhas.

A geopolítica confronta extremos, aparentados daqueles ocorridos por diferenças religiosas, sendo urgente relembrar, uma vez mais, as lutas bizantinas, voltadas à destruição de ícones, incitada pelo poder, entre os séculos VIII e IX, de modo a aprofundar a cissura - Ocidente e Oriente ${ }^{13}$. Não faltam religiões a venerar formas

\footnotetext{
${ }^{12}$ Cito, entre outras, a tragédia ocasionada pela Companhia Vale, que, ao final de setembro, em inúmeras mídias repetiu, ad nauseam, a inauguração do Instituto Cultural Vale chamada no projeto, Vale de Patrocínios Culturais.
}

\footnotetext{
${ }^{13}$ A importância de Bizâncio se deu em partes, em versão habitual, desde que o Imperador romano, Diocleciano mudou a administração (285) de Roma para esta, depois, Constantinopla e hoje Istambul. Outro, o Imperador Constantino (303-337), em lento processo, passou funções para lá, a incluir a religiosa, surgindo novos ritos. Agravou-se a cisão entre Oriente e Ocidente, por fatores como a Queda do Império Romano (485); adoção da língua e cruz gregas no lugar da latina (c. 620); e o primeiro Cisma da Igreja, então entre Roma e Bizâncio, ditando desligamento da Igreja Ortodoxa Oriental (1054).
} 
sacras (iconofilia), ajustadas às regras por elas firmadas, em embates acirrados contra opostos e seus símbolos, iconoclastia. O sentido etimológico desta, ou seja, "eikón" (ícone), designativo de imagem, mais "klastein", associado a quebrar, fraturar, evidencia-se o ato de arruinar valores, em diversos suportes.

Parecem desejar detonar obras, que revelam coragem, coesão e potência do adversário, ademais, alardear aura própria, por meio de narrativas sobre harmonia incomum, rara e estelar, dissimulando alvo e práticas em variadas épocas ${ }^{14}$. Sublinhe-se que o século XXI iniciou com enorme fresta e ultrajes iconoclastas, graças a dramas levados por espetáculo midiático, em escala global, sintoma nefasto do que poderia vir. Contrariamente a esta etapa, assistiu-se ao rancor e aversão a certas manifestações, advindos de fundamentalismo, contra o que não se é ou não se cultua, exibicionismo, discurso ideológico para abonar aniquilamento contra o que atrapalha intenções escusas, neste caso, ícones consagrados de povos eleitos como inimigos, para justificar coesão interna e fraqueza do outro.

No lugar de pregação e rezas, despontou chacina em atos arrasadores, em tempo real, com longo alcance. A intermediação por telas tornou mídias suporte de situações paradoxais, mediando visível e invisível e colocando cada um no centro do desastre. A estratégia gerou lazer mortífero, difundido em tempo real. Por outra face, expuseram a fragilidade de vários segmentos sociais, em particular daqueles em condições de penúria. Escancarou-se também domínio da tecnologia no lugar de técnicas; trivialidade de violência, vida e morte, banalizadas por chacina inserida no cotidiano e repetida sem cessar, a fundar o tempo das aparências em patamar diverso. Na presente pandemia, suavizou-se o drama a que parcela significativa

${ }^{14}$ Assinale-se, a perseguição de primeiros judeus e cristãos, que se reuniam nas catacumbas, se valiam de símbolos para coesão com pares e usavam o local para ritos especiais. Após o decreto do cristianismo como religião oficial pelo Imperador Teodósio (380) inverteu-se a perseguição, cristianizando-se lugares pagãos, seus objetos e edificações. Entre outras, em Roma, cito a igreja dominicana, Santa Maria sobre Minerva, antes templo pagão, segundo estudiosos seria dedicado a Ísis e não a Minerva; ou, a Igreja de São Bernardo nas Termas de Diocleciano. 
precisou se ajustar. Em crianças funcionou como jogo divertido, teatral e lúdico, o lado leve deste momento em que um inimigo desconhecido e ínfimo se espalha pelo planeta, exigindo \#fiqueemcasa, lave as mãos, para os que possuem residência e água encanada.

No final do século $X X$, sintoma dessa viragem se dera com difusão inaugural de televisão a cabo via satélite, pela rede $\mathrm{CNN}$, que permitiu seguir, no aqui agora, a nomeada Guerra do Golfo, entre agosto de 1990 e fevereiro de 1991, a partir de Bagdá. Alegava-se então proteção ao Kuwait da ofensiva e indexação feita por Saddam Hussein ${ }^{15}$. Sobravam cenas incomuns com bombardeio, mísseis lançados de porta aviões e corpos estilhaçados, como troféus lúgubres. A fascinação pelo inédito gerou diferencial na grade da TV, evidências funéreas da fissura em se seguir ao vivo lances excêntricos. No entanto, o visto nessa ocasião não se equipara a dois terríveis choques entre Ocidente e Oriente, ao se iniciar o século XXI

De março a setembro de 2001 germinaram transmissões sinistras de duas hecatombes, divulgadas em escala global, a envolver novas personagens, trajes e valores culturais, encobertos na cena Ocidental. Em março, na localidade de Bamiyan, região central afegã, dois enormes monumentos dedicados a Buda foram dinamitados, durante dias, segundo se noticiou, por iniciativa assumida de líderes do Talibã. A ação, além de terrificante, incidiu em simbologia que afrontou o conceito de inovação e patrimônio, no Ocidente. Outra deu-se a 11 de setembro de 2001 no World Trade Center, ditas Torres Gêmeas/ Nova York, que foram detonadas por ataques de aviões, em show midiático hollywoodiano, reivindicada pelo grupo Al-Qaeda, de Osama Bin Laden. Ademais, atingiram o Pentágono, Departamento de Defesa estadunidense, centro do poder, localizado na capital do país, Washington DC.

Os Budas do Vale de Bamiyan teriam sido esculpidos por escola artística dessa religião, na antiga Bakhtria, como se informa no site da Unesco. Situados na Rota das Sedas, a ligar China e Índia, há anos lá se mantiveram invioláveis. As autoridades alegaram rejeição ante a tentativa para incorporá-lo à lista de Patrimônio Cultural da

\footnotetext{
${ }^{15}$ A reação foi liderada pelos Estados Unidos, com Georges W. H. Busch e na Inglaterra, por Margareth Thatcher, apoiados por alguns países e respaldados pela ONU (Organização das Nações Unidas).
} 
Humanidade, o que de fato se efetivou em 2003, na condição de Paisagem Cultural ${ }^{16}$. Como esperado, defenderam a violência, com elevados princípios. Neste caso, os Talibãs alegaram revolta por oferecerem recursos para monumento edificado e não para prover auxílio às crianças, que estas vivem em condições cruéis, negando se eximir da própria culpa por esta condição.

Reações imediatas surgiram em setores artísticos, a incluir mostras, grifando que exposições são propostas com muita antecedência: entre 4 de maio e 1 de setembro de 2002, organizou-se a mostra Iconoclash. Beyond the Image Wars in Science, Religion and Art, no Centro de Arte e Mídia (ZKM), em Karlsruhe/ Alemanha. Reuniu o pensador Bruno Latour e o artista Peter Weibel, ao lado de renomados estudiosos ${ }^{17}$. O título se justificava como choque iconoclasta, no texto de Latour e que se encontra na epígrafe da parte a seguir deste estudo, um claro diálogo com as ocorrências referidas. Diferencia-se então Iconoclasmo de Iconoclash, afirmando que quanto ao primeiro, sabem-se as razões e o que se passa no ato de investir contra. Já para Iconoclash não há a referida certeza "[...] quando se é perturbado por uma ação para a qual não há maneira de saber, sem uma investigação maior, se é destrutiva ou construtiva" $(2008$, p.113).

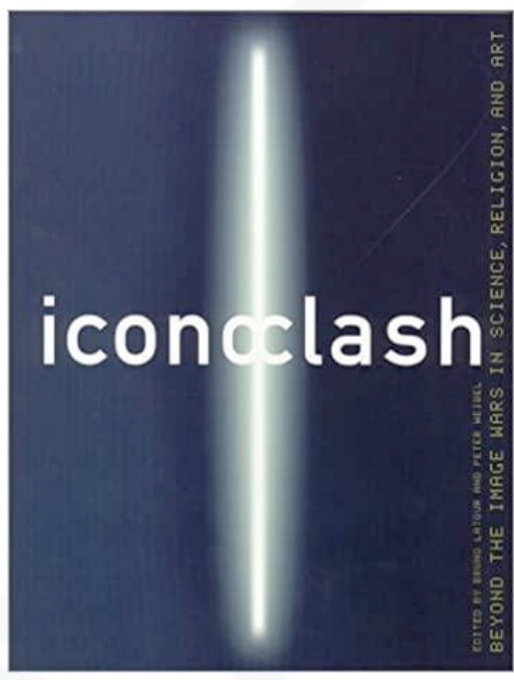

\footnotetext{
${ }^{16}$ Em 1992, o Comitê do Patrimônio Mundial, em sua 16ạ sessão/ EUA inclui a categoria “Paisagem Cultural" na Lista do Patrimônio Mundial da Unesco.

${ }^{17}$ Peter Galison, Dario Gamboni, Joseph Koerner e Hans U. Obrist, apoio de Hans Belting, Marie-José Mondzain, Heather Stoddard, Boris Groys e Denis Laborde.
} 
Figura 2: Capa do livro editado por ocasião da exposição Iconoclash. Beyond the Image Wars in Science, Religion and Art. Fonte: Site do Museu.

Constatam-se ações, a espelhar assombro, também em filmes, embasados nos dois citados choques, embora antes outros previram situação apocalíptica semelhante, em que cidades e pessoas foram implodidas ${ }^{18}$. Destaco, entre tantos, em 2004, aquele que conquista a Palma de Ouro no Festival de Cannes "Fahrenheit 11 de Setembro" (2004), documentário realizado pelo diretor Michael Moore. Igualmente em 2007, a cineasta iraniana Hana Makhmalbaf apresenta o filme "E Buda desmaiou de vergonha", com foco também para um grupo de garotos que apedreja uma menina por desejar estudar, algo proscrito para esta. Atacam-na aos pés das obras destruídas, como aduz o título, valendo-se de pedaços remanescentes do monumento em que brincam, sem se dar conta dos destroços, ambos naturalizados.

O conjunto de catástrofes foi decisivo para essa viragem de se cultuar a imagem, quase como um pêndulo entre paixão, ou iconofilia versus iconoclastia, como se constata em estudos $^{19}$. Entre as questões propostas, cito a pensadora Marie-José Mondzain no ensaio "Pode a imagem matar?" (2002). Afirma sobre o 11 de setembro de 2001, que se deu "o maior golpe a esse império do visível". E acrescenta que se organizara "[...] um espetáculo aterrador, o primeiro espetáculo histórico da morte pela imagem na imagem da morte [...] e foi preciso enterrar os cadáveres com toda a rapidez e manter o discurso do triunfo e da ressurreição" (2009, p.11). Reitere-se que os EUA eliminaram vestígios imagéticos capazes de desnudar o contraste entre a força destrutiva e a fragilidade na defesa, ostentada como inviolável, apelando para barbárie de não ocidentais. Sublinhe-se, além da inexistência de registro com corpos carbonizados, o

\footnotetext{
18 Entre outros: a) "O inferno na Torre" (1974), direção de John Guillermin, em que um incêndio destrói um edifício; b) "Independence Day" (1996), de Roland Emmerich, em que alienígenas invadem a Terra, atacam cidades e no caso de Nova lorque/NY detonam o Empire States; c) "Impacto profundo" (1998); o de Mimi Leder, em que um asteroide iria chocar-se com a terra em NY e, ao cair parte deste, gera um tsunami que dizima a referida cidade.

${ }^{19}$ Cito Hans Belting - Antropologia da imagem (2002); Georges Didi-Huberman - L'Image survivante. Histoire de l'art et temps des fantômes selon Aby Warburg (2002); Images malgré tout (2004). Jacques Rancière - Le destin des images (2003).
} 
mesmo ocorreu quanto ao choque com Pentágono, a incluir ausência de fotos e filmes na coleção do Memorial e Museu Nacional 11 de Setembro, em Nova York.

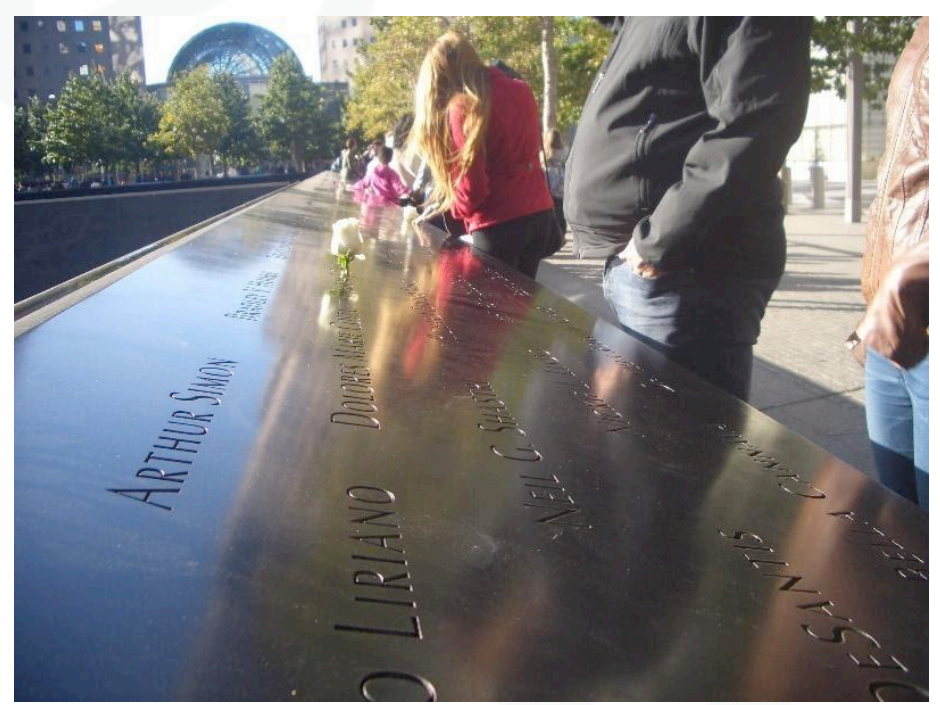

Figura 3: Memorial e Museu Nacional 11 de Setembro. Fonte: foto A. em 10 fev. 2016.

As referidas agressões foram permeadas por show feito por imagens-ícones, via telas, estas funcionando também como frestas, seja de TV, filme, internet fixa ou móvel, causando experiência imersiva pública em espaço doméstico. As telas móveis ou fixas viraram o meio entre extremos polarizados, rejeição ante horror, sublime e aterrorizador, próximo à iconoclastia religiosa ${ }^{20}$; de outra forma surgiu encanto irresistível e aproximada da iconofilia a essa mídia, como bem definiu Bruno Latour.

No cotidiano infiltraram-se aniquilamento, população civil aviltada, garantia de defesa abalada, criações humanas em ruínas por poder, razões armamentistas, financeiras, ideológicas, ultraje a valores locais, retórica bélica e confronto de signos. Cabe sublinhar que nunca as representações foram neutras, sendo usados os recursos com sutileza, seja político, imperial, governamental, real ou religioso, ontem e hoje. Cores, ritos, formas e palavras recobrem intenções de mando e centralidade, para ficar longe e no passado.

\footnotetext{
${ }^{20}$ O termo iconoclastas, desde Bizâncio, aponta para a destruição de imagens como forma de poder contrário ao que estas podem querer simbolizar em determinado culto religioso.
} 


\title{
ATRAÇÕES DISTINTAS POR IMAGENS
}

\begin{abstract}
"O que aconteceu, que tornou as imagens (e por imagem queremos dizer qualquer signo, obra de arte, inscrição ou figura que atua como mediação para acessar alguma outra coisa) o foco de tanta paixão? A ponto de destruí-las, apagá-las, desfigurá-las se ter tornado a pedra de toque para provar a validade da fé, da ciência, da perspicácia, da criatividade artística de alguém? A ponto de que ser iconoclasta parece a mais alta virtude, a mais alta piedade em círculos
\end{abstract} intelectuais?' (LATOUR, 2008, p.113).

Dialogando com Bruno Latour na epígrafe, aqui se indaga: o que mudou para emergir atração, entre tantas, por obra-prima, tão reproduzida, exposta, aplicada em lembrancinhas, em particular as Quinhentistas, ou as Seiscentistas, antes do fechamento de museus? O ato de quase "apagá-las, desfigurá-las [...]" (LATOUR, 2008, p.113) seria apenas mimetismo, o que se desmente por releituras, a ultrapassar a cópia, avizinhando-se de criação, em ações na Covid-19? Ao reinterpretar originais, até por meio de deboche, ocorreria dessacralização e familiaridade das ditas obrasprimas? O jogo permitiria passar de distante para o próximo, de ótico para o táctil, de inaudível para sonoro, de banalizado para portador de aura? Os clássicos estariam tão fetichizados, que a familiaridade se mudou para ironia, como desde os Anos 1980 se viu em ação de artistas ironizando a obra-prima?

Entre tantas experiências, fendas e sintomas previstos pela criação, cabe ressaltar a intenção nos Anos 1960 em mudar a visão e interpretação tradicionais em relação às obras de arte. Lembraria, que antevendo o futuro, uma vez mais, artistas como Robert Morris (1931-2018) e Carolee Schneemann (1939-2009) realizaram performance em 1964, citando Olimpia de Édouard Manet (1832-83), na modalidade tableau vivant. Nesta repetiram-se os gestos até se figurar exatamente a cena do citado quadro. Em relato posterior, a artista dá pistas sobre suas práticas inovadoras, ao declarar algo para se refletir sobre aquelas e as atuais. Afirma intenção em ampliar o sentido táctil na visualidade, para além dos contornos de espaço e tempo (REILLY, 2016, s.p.). Então, ao se restringir o humano por isolamento social, talvez se 
sintam expandidos pela arte, rompendo limitações e restrições espaciais, em que se viram, em especial crianças, familiares e escola, nesta pandemia.

Cindy Sherman (1954), desde o final dos Anos 1970, incorporou numerosos papéis, registrados por montagem no próprio corpo, registradas em fotos feitas por ela, eivadas de questionamentos. A artista incluiu poses em clichês, estereótipos sobre gênero, erotismo, grotesco e mutação da face e corpo feminino em mercadoria venal, aqui também como se afere em suas redes sociais. Em que pese a crítica negativa, em 2011 uma dessas obras foi leiloada por US \$3,89 milhões, assim reiterando que desvios, afronta e contradições sempre são atraídos pelos poderes, embora no caso dela, sem paralisá-la.

A artista assume habituais posturas de estrelas, não apenas em filmes, mas também em capas de revistas, que se expõem na indústria cultural, sendo espalhados nas cidades. Realizou réplica de telas célebres quando morou em Roma entre os anos 1989-90, na série History Portraits or Old Masters, em que empregou próteses no corpo para ampliar volume e confrontar fetiche relativo a determinadas obras renascentistas, a gerar também forte interesse. Insiste em afirmar que as interpretações resultaram não em vê-las nas coleções romanas, mas sim, baseandose em reproduções. Coincidem com a época em que circularam, terríveis imagens sobre AIDS (Síndrome da Imunodeficiência Adquirida), em mídias expondo corpos dramáticos, dilacerados por aquela síndrome.

A paródia humorada ou grotesca de obras de arte, ao florescer este século, derivou para espaço reflexivo em diálogo com os transeuntes, em grandes e pequenas cidades, reavivando o sonho moderno, da arte invadindo o cotidiano, já ativo na Bauhaus. Surgem manifestações na arte urbana, juntamente com grafite, agora com projeções, papel impresso e colado na parede (lambe-lambe); sticker, etiqueta adesivada em distintas superfícies; estêncil, molde vazado e que pode ser repetido em várias superfícies; a agudeza da pichação, ou pixo, para citar alguns. Em geral utilizam-se frases e total ausência de encomenda, curadoria ou autorização, logo, sem acordos, prática adotada antes nos muros parisienses, em maio de 68, com o famoso "Proibido Proibir", iniciativa de docentes e alunos da Escola de Belas Artes local. 
As formas adotadas nesta pandemia dialogam com instalações artísticas, por duas vias: de um lado, contracenam, reconhecem o espírito e a cultura material do local; também contracenam com propriedades de forma, cromatismo, tempo e lugar; por outro, prevalecem sutis arranjos, a honrar a sensibilidade e inteligência, tanto da plateia urbana, quanto de espectador isolado. Valem-se de imagens e letras; realizam crítica social, política, cultural, abundantes neste interstício, aqui e no mundo, na e antes da pandemia do Covid-19.

Inúmeros experimentos fogem do decorativismo de belas formas, interesse de elegantes espaços; no lugar de apenas repetir ou espelhar, interpretam, protestam e alertam, em crônica sobre desvios do momento e aptidão em atrair olhares ${ }^{21}$. Observe-se a obra a seguir feita pela "Gráfica Fidalga/ SP, em lambe-lambe voltada à humorada crônica sobre selfies e fetiches, que convive com folhas ao chão, contígua à dadas poéticas, sem esconder muros em que se constata a espoliação de Cronos. Obra anterior à pandemia, em que se utilizaram dessas pinturas célebres, aliás ambas com grande penetração, na atual pandemia, como se verá.

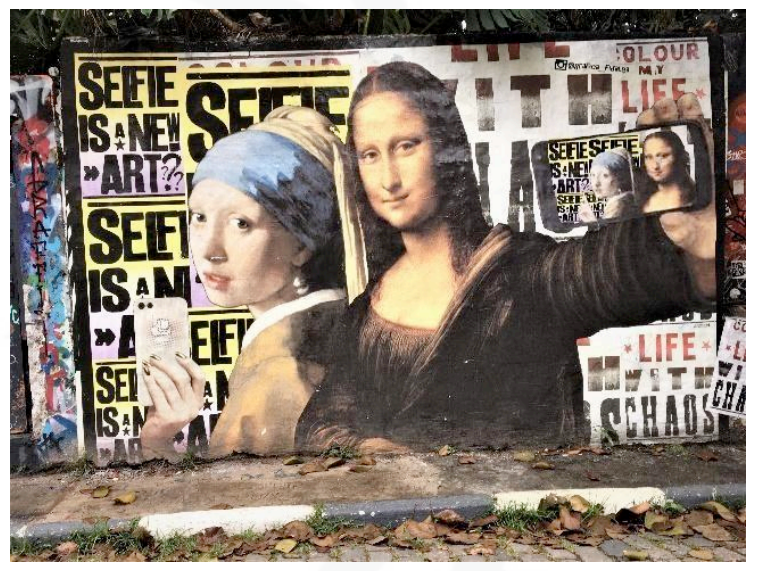

Figura 4:- Gráfica Fidalga. Lambe-lambe no Beco do Batman/SP. Fonte: foto A. 22.09.2020

Sem se discutir o real mérito dos artistas, a hipótese de excesso e mega divulgação fica bem documentada na ironia junto aos afrescos e esculturas de consagrados

\footnotetext{
${ }^{21}$ Agradeço ao pessoal da disciplina de Pós da FAU USP, "Arte para Cidade" pelas trocas de olhares, expressões e reflexões, sobre o lambe-lambe, na visita técnica ao chamado Beco do Batman, na capital paulista, em 22.09.2020.
} 
artistas, como Michelangelo Buonarotti (1475-1564), capazes de produzir memes ${ }^{22}$. Cito A Criação de Adão, na Capela Sistina, composição esta que sensibilizou mais adultos com sarcasmo e tédio pela situação. Apareceram desde Deus com luvas, vaporizador com álcool gel, no dedo estendido de Adão, acendendo cigarro para este e caído como uma garrafa a seu lado; ou ambos tocando-se cada um em um automóvel, alusão ao drive thru da pandemia para uma série de atividades. Mutações do original voltaram-se a moças de biquíni na praia com as mãos na mesma posição; dois rapazes cercados por latas de cerveja; um meigo gato-Adão tocando Deus, aliás usado em muitas obras clássicas; 10 mil marshmallows para refazer as nuvens, que os envolvem; colegas relaxando em sofá de escritório com as mãos a repetir o gesto da obra.

A obra David de Michelangelo, na Galeria da Academia, em Firenze/ ITA, igualmente atraiu grande interesse, via paródias, arremedos e humor. Ganhou nome de "David$19 "$, além de óbvias máscaras a recobrir a face; fez-se mimetismo da pose corporal, mas, em crítica, pois, há pessoas vestidas; projeção de imagens em partes do corpo; virou super herói; mudou sexo e postura assumindo a de corredor; também ajoelhou, levantou peso e ganhou bermuda, roupa de praia com óculos de sol e uns quilinhos, como tantos sem poder circular, sendo todas virtuais e compartilhadas em escala gigantesca.

Novidade estimulante e não apenas para os mais novos, apareceu em aplicativos lúdicos, que fazem emergir ferozes ausentes, como se estivessem próximos ${ }^{23}$. Ampliaram, então, o cotidiano restrito em que boa parcela se viu isolada. Ainda que em espaço do quintal doméstico, os recursos atraíram crianças, aproximando-as de forma mágica ao mundo natural, em especial de brutais felinos, agora domesticados e ao alcance de suas mãozinhas. O resultado favoreceu a transposição delas a

\footnotetext{
22 Segundo se consagrou, "meme" surgiu no livro "O Gene Egoísta" (1976) do biólogo Richard Dawkins. Nesta era adaptou-se e indica unidade, que se multiplica com celeridade e em grande quantidade em mídia digital.

${ }^{23}$ Agradeço em especial ante o compartilhamento de imagens em aplicativos e releituras aos familiares e jovens intérpretes, que aqui estão documentados: Enzo, Isabel, Sophia, Marina e Gael.
} 
espaços luminosos, imaginários em telas, de forma lúdica e situação excepcional, originando expressões de espanto, cuidado, coragem e orgulho de sua façanha na cena, quando ladeado por animais, como se observa a seguir.

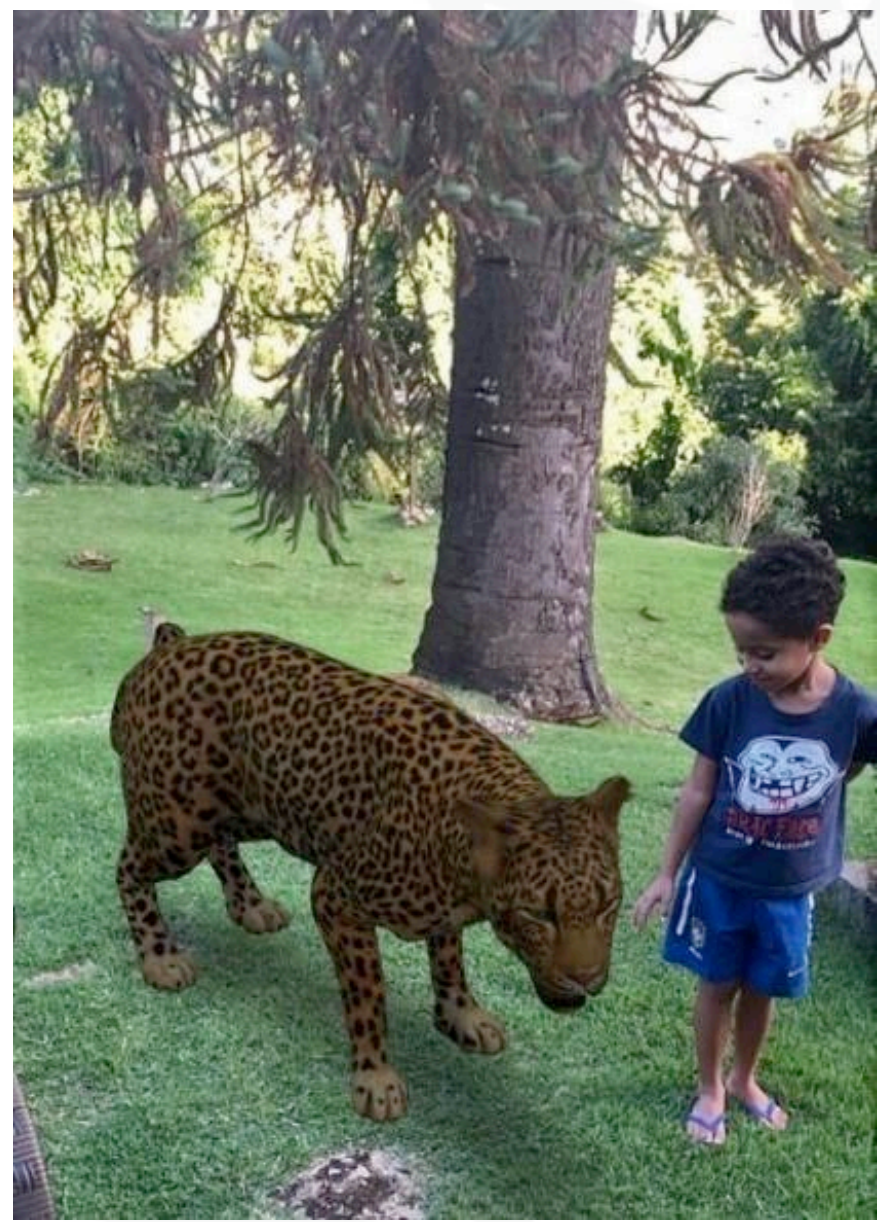

Figura 5: Enzo Lourenço Matiello. App View 3D. Fonte: foto Naia Lourenço Matiello em 28.03.2020

Em paralelo, múltiplas interferências foram escolhidas para interagir, como a Monalisa de Leonardo da Vinci (1452-1519), fragmento ecoado em larga extensão. Já a releitura com toques de humor e erotismo nas escolhas ficou mais por conta dos adultos, como se observa em arquivos digitais sobre hilárias escolhas. Não faltaram gatinho no colo, itens de limpeza, rolos de papel nos braços, bobes no cabelo, perna esticada na consagrada paisagem; imaginou-se chopp nas mãos e apareceu em novo visual, seja cabelo com cachos, trancinha, ou franja, enfim, extravasou-se a vivência de alguns. 
As imagens aludiriam ao inconformismo, desespero, revolta à compulsão higienista, apelo reiterado por máscaras e isolamento social. Neste último tópico, a mesa da Santa Ceia de Da Vinci ficou sem personagens, seguindo o que antes antevira o artista José Manuel Ballester (1960), na série Espaços Ocultos (2007-8), encontrada no site do artista, quando retirou personagens de quadros clássicos, datados entre séculos XV ao XIX, restando grave vazio, perpassado por inquietante silêncio pela ausência forçada daqueles. Neste caso, relacionam-se às dúvidas e inquietações, não controladas, nas várias instâncias e profissões ante a Covid-19.

A utilização da celebrada obra Moça com Brinco de Pérola (1665), de Johannes Vermeer (1632-75), chamada Mona Lisa do Norte, também conquistou ampla recepção e procedimentos bem diferenciados. Despertou a atenção para detalhes, nem sempre percebidos por adultos, sendo em outros, alterada em livre comentário, fazendo toda a diferença na criação e resultado. Atente-se ao torso virado, olhar eivado por mistério e indagação: a garota do quadro teria sido chamada ou atraída por algo? Também procede de visão acurada, o uso de gola branca, traje escuro e o famoso brinco, sutilmente escolhido ao se revisitá-la para/por crianças. Igualmente as tonalidades gerais da obra e o turbante oriental conferem vivacidade no que já se chamou por quadro ao vivo (tableau vivant), materializado com empenho pelas meninas, cada qual dedicada a seu papel. 
a.
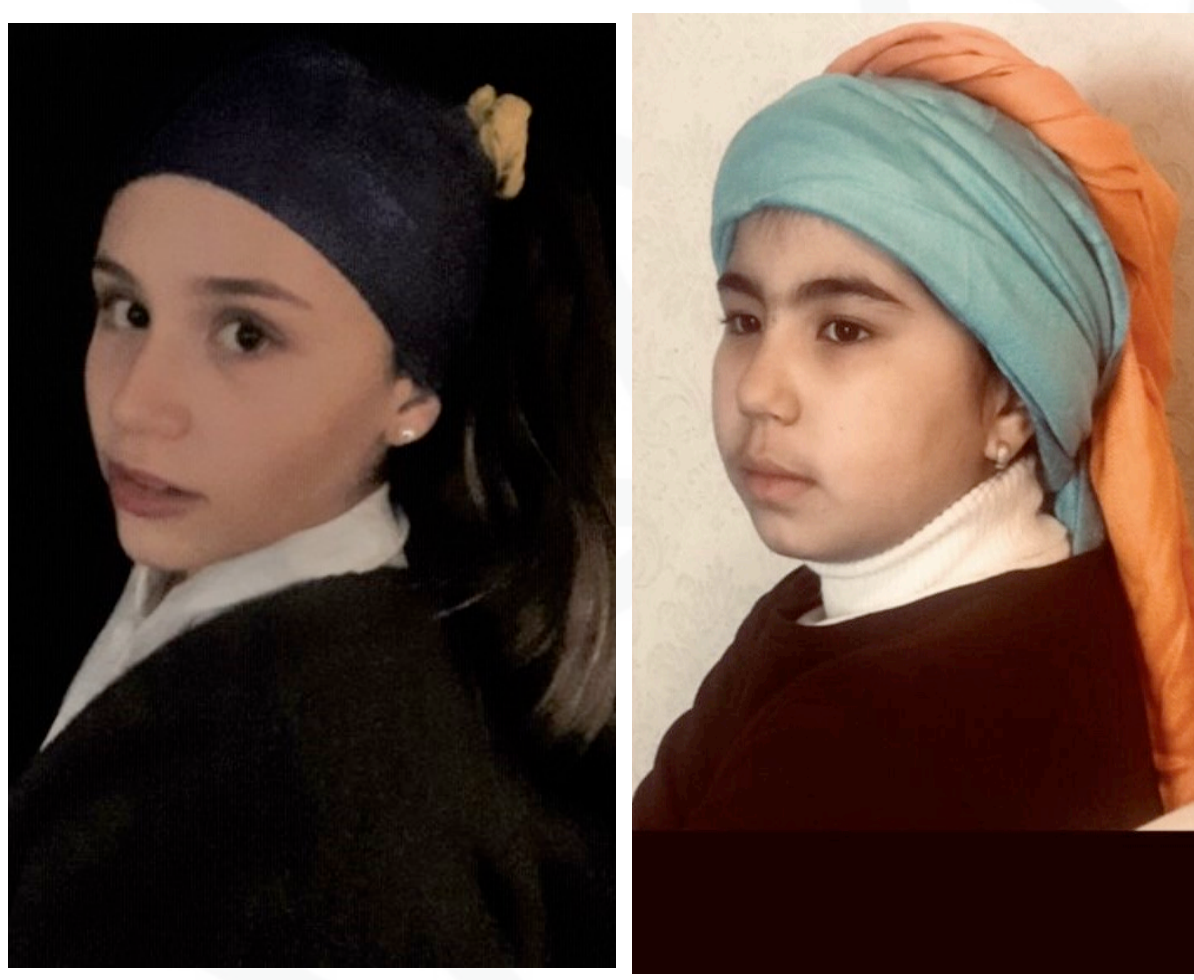

Figuras 6 e 7: "Moça com Brinco de Pérola” de J. Vermeer. Reveem: a) à esquerda: Marina Oliveira Dib. Fonte: foto Gisele Oliveira Dib; b) à direita: Sophia Amaral Ruggiero. Fonte: foto Letícia Amaral Ruggiero.

Atente-se que a modalidade, quadro vivo, surgiu no final do século XIX, após a invenção da fotografia, uma forma de revalorizar pinturas, antes preferidas para fixar retratos e cenas. As pessoas se vestiam simulando poses, trajes, ambientes e postura corporal dos quadros mais divulgados. Na era da internet, retorna tal prática, também elegendo certos ícones. Seria citação de mídias anteriores, agora em crise? A tela de Vermeer e a de Da Vinci exibem relações: suscitam interesse incomum nos museus, embora possuam pequena dimensão ${ }^{24}$; parecem não possuir sobrancelha realçada e se pergunta: para que lugar olham, de forma emblemática? A ausência de contornos ajudaria a impressão de que elas não têm os pelos acima dos olhos? $\mathrm{Na}$

\footnotetext{
${ }^{24}$ A tela de Vermeer mede $44,5 \times 38 \mathrm{~cm}$ e a de Da Vinci, $77 \times 53 \mathrm{~cm}$.
} 
obra holandesa, a área escura seria menos importante por não ser opção do artista, ou encobriria habituais formas ocultas, desvios, indecisão, erro do artista?

Ressalte-se, uma vez mais, a acuidade em se ir além da aparência ou tema, por meio de pesquisa, e o museu holandês, desde 2018, com tecnologia avançada, descobriu novos dados, divulgados em seu site. Não seria um retrato, mas sim um trone em termo de época, na Holanda, ou seja, um rosto típico, ou conjunto habitual. Análise na camada escura trouxe dado inédito, de que ela se encontra em frente a uma cortina verde, que teria sumido por ação de tempo, agentes físico, químico e ambientais. Em grande parte, o mistério latente, na obra de Vermeer, decorre de brilhos acentuados, nos lábios, olhos, turbantes, parecendo oriental, e a pérola na orelha furada, capaz de ampliar perguntas e simbologias ocultas. Pertence à Real Galeria de Arte Mauritshuis / Haia HOL que abriga a coleção de Maurício de Nassau ${ }^{25}$. Assinale-se que foi celebrizada em filme de Peter Webber (2003), baseado no romance de Tracy Chevalier (1998), sobre a personagem feminina, que centraliza a tela. Note-se que o texto antecedeu às investigações em 18 anos daquela feita por pesquisadores da Real Galeria Mauritshuis, desta forma revelando a capacidade inventiva e narrativa da escritora. No filme, ressaltam a cenarização de época, enigmas, imaginação e variados efeitos lúmicos, com janelas e aberturas a indicar recursos usados na chamada Era de Ouro da Pintura Holandesa, como uso de câmera escura, lentes e espelhos, tese bastante difundida ${ }^{26}$ (HOCKNEY, 2001, p.196).

A atenção distinta em detalhes perpassa o filme de Weber, fixando-se em minúcias pictóricas do artista, realçando-se, o amplo uso de azuis, feitos da pedra obtida no Afeganistão, nomeada por lazulita semipreciosa e então obtida a preço de ouro. Estes transbordam no cromatismo presente na filmagem, ao lado de tons terrosos e métodos de ofício e ferramentas. Sublinhe-se que as cenas criadas pelo artista em

\footnotetext{
25 Vindo dos então Países Baixos, Nassau aceitou a função da Companhia da Índias Ocidentais para administrar a nomeada, Colônia no Norte, no hoje Brasil. Ficou entre 1636-44, quando voltou a Haia, com coleção de exotismo, que definiam sua identidade. Em 1828 o governo holandês adquiriu a coleção.

26 Ver o vídeo do artista David Hockney, Secret Knowledge BBC. Há um livro em português.
} 
sua pequena produção serviram de referência para complementar o conjunto fílmico. Ampliou-se também a paixão por essa imagem, quando entre 2012-14, para reformar a edificação, circulou em exposições nos EUA e Japão em mostras a atrair multidões em busca de ingresso, selfies, alarde em mídias, na chave de apreciar a chamada "Mona Lisa do Norte". Na volta, a instituição alegou que não sairia mais, para atentar à preservação. Assinale-se que tais empréstimos, na atualidade, rendem capital simbólico, a par de recursos financeiros, aqui conforme explicou o museu, para requalificar a sede ${ }^{27}$, reaberta em 2014.

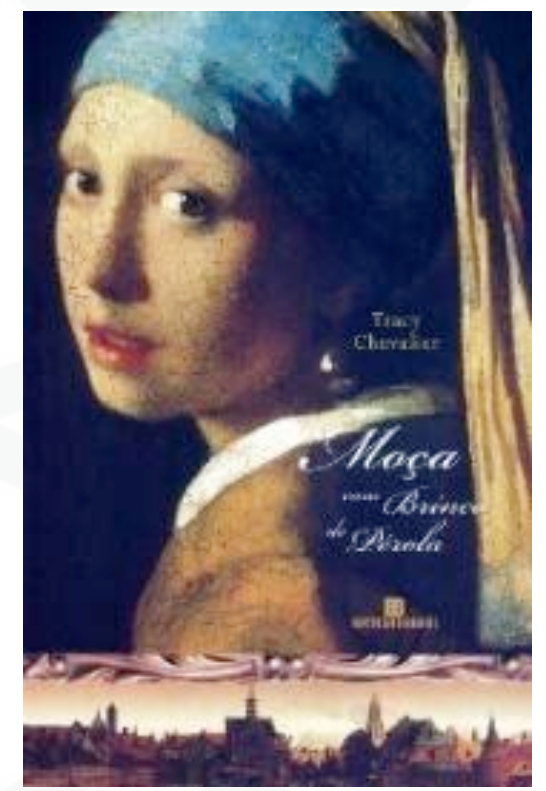

Figura 8: Capa de livro de Tracy Chevalier. Fonte: Site da Editora

\section{VESTíGIOS E AÇÕES}

"À mais perfeita reprodução falta sempre algo o hic et nunc da obra de arte, a unidade de sua própria presença no próprio lugar em que se encontra existência única, no lugar em que ela se a encontra. É a esta presença única, no entanto e só a ela que se acha vinculada toda a sua história. Falando de história, lembramo-nos também das alterações materiais que a obra pode sofrer de

\footnotetext{
${ }^{27}$ O projeto foi de responsabilidade do arquiteto Hans van Heeswijk (1952) e equipe.
} 
acordo com a sucessão de seus possuidores. Os vestígios das alterações materiais só ficam desvendados em virtude das físico-químicas ou físicas, impossiveis de serem feitas numa reprodução; a fim de determinar as sucessivas mãos pelas quais passou a obra, deve-se seguir toda tradição, a partir do próprio local onde foi criada" (BENJAMIN, 1975, p13.)

Destruição da aura por reprodução técnica se observa entre as preocupações de Walter Benjamin, em face do então avanço da imagem reproduzida, com possibilidade de eliminar o espectador diante dela. O visitante esteve lá e telas, esculturas e objetos permanecem no museu, quando este se afasta. Naquele tempo, o registro por técnicas e agora a ego viagem, nomeada por egotrip nas redes sociais, talvez revelem desejo em comunicar-se exibindo-se selfies, intimidade, refeições de modo incontrolável para alguns. Seria, talvez, certa dose de expor o que habitualmente se considera distintivo pessoal? Benjamim incide na análise de vestígios para firmar autenticidade, pois perderiam a atração e capacidade, se a fruição ocorresse de forma não direta, por aparelhos, então filmes e fotos.

O uso de transmissão online esteve restrito aos museus em situação menos dramática e que já operavam em plataformas como Wellcome Collection, Google Arts \& Culture $^{28}$, "Era Virtual", esta última criada em 2008 e voltada aos museus brasileiros, além de Facebook, Instagram, Twitter e outros. Os demais viram-se compelidos a afastar pessoal em condição de risco, deslocar alguns para atividades cotidianas de conservação e controle de obras. Assim, estes órgãos puderam valer-se de interatividade com espectadores, em várias faixas. Redução de circulação e pessoal não foi impune, havendo roubo de obra, como o declarado sobre a pintura Spring Garden, de Vincent van Gogh (1853-90) do Singer Laren Museum, na Holanda, 18 dias após o fechamento (30.03.2020). Teria havido outros não veiculados?

Se Benjamin alude ao despontar do cinema com várias objeções, caberia inquirir: e na era tecnológica, bombardeando imagens, em especial na pandemia, quais as

\footnotetext{
${ }^{28}$ Antes denominado Google Art Project e com inúmeros museus, usa tecnologia street view com possibilidade de percorrer espaço em $360^{\circ}$ e o acesso em geral ocorre pelo site dos museus.
} 
alterações preocupantes emanadas? A indagação pode ser favorável ao se dar conta das inúmeras encenações criadas por futuros visitantes. Com o passar do tempo, quem sabe ao se deparar um dia com essa obra reconheçam como antes se esforçaram para torná-las vivas na telinha, durante a quarentena, enclausurados em suas casas. Ainda seriam atraídos por analisá-las com esmero para além do simples tema, como se constata nas releituras ${ }^{29}$ selecionadas?

O conjunto aqui reunido gira em torno daqueles protagonistas, cuja idade indica que os pais, por mais ativos, não conseguem interferir ou exigir imobilidade controlada, por longo tempo, em particular nas expressões faciais e com seriedade teatral. Tratase de mérito deles desempenhar o papel. Chama a atenção como as pinturas puderam ser bem reinterpretadas com sutil variação, fixando pormenores e improvisando cenários. Incluíram-se até telas menos expostas, como "Moça com livro", de José Ferraz de Almeida Júnior (1850-99). Ressalte-se que esta foi doada ao MASP (Museu de Arte de São Paulo), quando da inauguração, em 1947 naquelas ruidosas campanhas feitas por Francisco de Assis Chateaubriand.

\footnotetext{
${ }^{29}$ Em 1984, elaborei o Projeto Releitura de obras pertencentes ao acervo da Pinacoteca do Estado/SP, escolhidas por artistas e, ao final, discutidas com o público museal.
} 


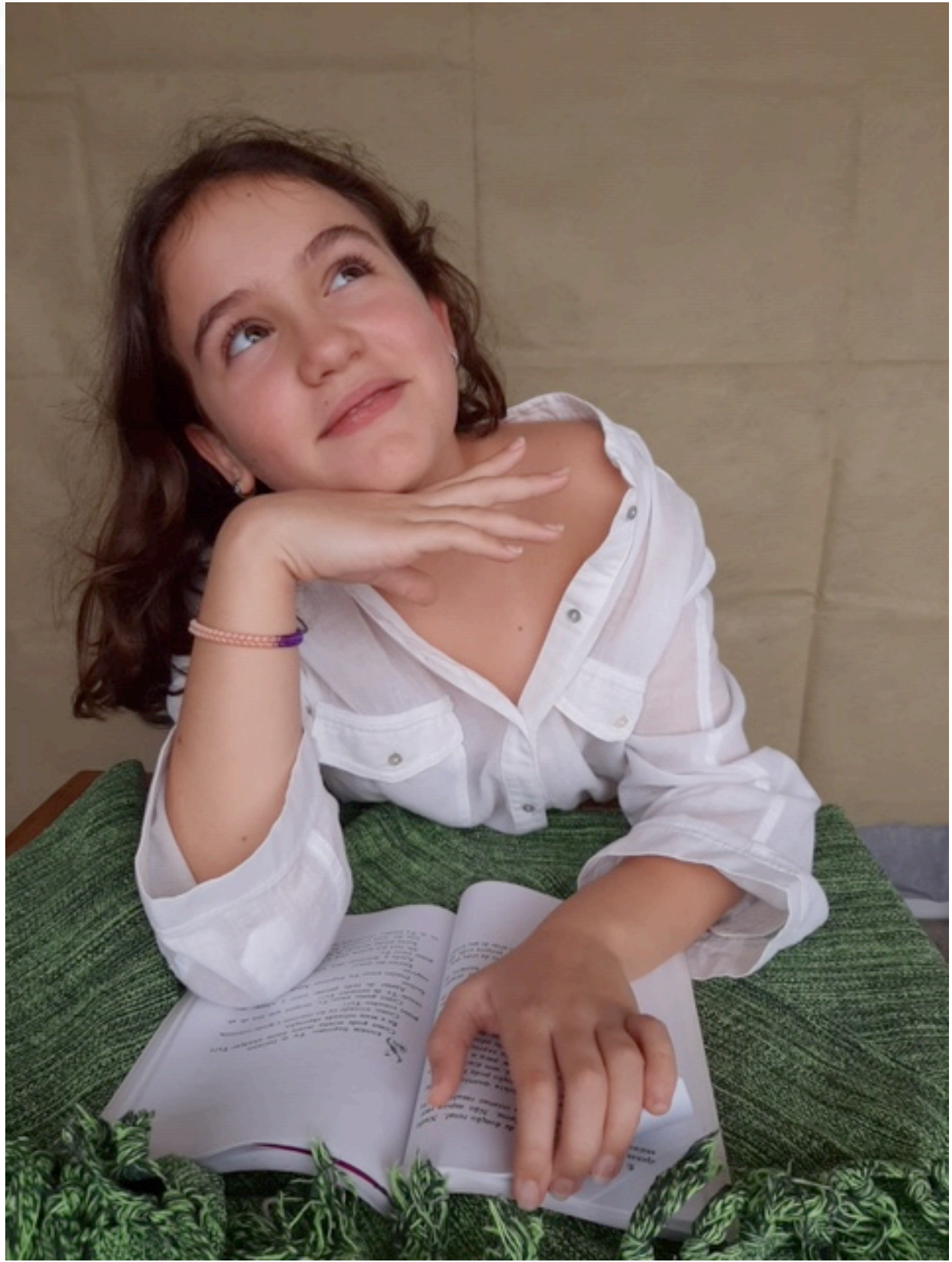

Figura 9: "Moça com Livro" de José Ferraz de Almeida Júnior (MASP). Encenada por Isabel Oliveira Dib. Fonte: foto de Gisele Oliveira Dib

A coleção notável do pintor, a unir figura humana e paisagem se localiza na Pinacoteca do Estado/SP e no Museu Paulista/USP, o que resulta na atração de jovens pesquisadores para analisá-las em estudos universitários, verdadeiro arsenal de reflexões, por mim acompanhados com interesse e admiração, em bancas e consultas. Naquele museu, encontram- se as obras regionalistas, em que Almeida 
Júnior fixa, com veemência, expressão corporal, cotidiano, casa, ferramentas e, mesmo, descanso da lida. Insiste na força de personagens interioranas, em diálogo com o espaço. Ao contrário, na pintura do MASP, traz algo extraordinário - uma jovem leitora, em tempos em que tal atitude era bastante limitada para mulheres. 0 livro ocupa o primeiro plano e a vaidade se encontra documentada no uso de batom, esmalte nas unhas e rosto rosado. Nada disso passou despercebido na releitura.

Como afirmei na publicação editada por ocasião da exposição, "Almeida Júnior um criador de imaginários", na Pinacoteca do Estado, a obra "Moça com Livro" (MASP), o pintor agrega distintos sentimentos. Por um lado, uma blusa cor da pele da modelo gera ambiguidade; de outra parte, indica devaneio e concentração, aquele sentimento obtido por meio da mão que sustenta o queixo, enquanto, ao marcar a página parece indicar que seguirá na leitura (LOURENÇO, 2007, p.191). O olhar enviesado para o alto reforça a expressão indagativa e o texto impresso fica bem evidenciado, ante a proximidade da observação, parecendo ter usado máquina fotográfica, que localizei no inventário dele. Curiosamente, tais minúcias fundaram o centro da encenação realizada acima, acrescentando adaptações curiosas, como a da grama improvisada por tecido e pulseira, que bem complementam a cena.

Artistas brasileiras conquistaram lugar nessa voga de reparação, que movimenta mercado de arte, entre as escolhas lembro a de obras de Tarsila do Amaral (18861973). Esta vem recebendo merecida atenção, em parte, em ações amparadas em inúmeros estudos pioneiros, com ela em vida, alguns reunidos aqui na Bibliografia e empreendidos por Aracy Abreu Amaral. Lembraria que recentemente expôs-se a produção desta, no celebrado MoMA NY EUA (Museu de Arte Moderna), com título, Tarsila do Amaral: inventing Modern Art in Brazil, constituída por amplo conjunto (130 peças) e difusão massiva, entre 11 de fevereiro e 3 de junho de 2018. No ano seguinte, montou-se mostra imersiva no Farol Santander / SP, Tarsila para crianças, entre 26 de novembro de 2019 a 23 de fevereiro de 2020, com cenários, objetos, reprodução de animais reais ou imaginários, animação de fragmentos, cores, sons variados, sensação táctil de algumas pinturas, a partir de obras apresentadas da artista. 


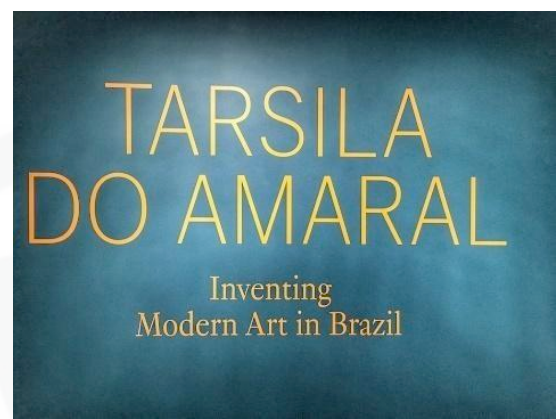

Figura 10: Painel na entrada da exposição no MoMA. Fonte: Site do MoMA

Obras, em espécie de tableau vivant, conquistaram análises acuradas, a merecer reflexão. Veja-se a de Tarsila do Amaral "Boi na Floresta", de 1928, do Museu de Arte Moderna / Salvador, Bahia relida em detalhe, nem sempre fixados por adultos. Incluiu-se aqui atenção ao projeto compositivo, escala, relações entre as partes, efeitos luminosos, cromatismo, textura e contrastes. Como uma crônica e usando economia de recursos surgem adaptações, por meio de objetos e espaço doméstico, a partir de seleção: fundo de parede em lousa da própria casa e linhas em giz branco apontam e delimitam troncos em azul da floresta na tela; almofada funciona como chifres do referido animal; postura corporal garante quatro apoios; e a expressão facial valoriza a força deste. Neste caso, em depoimento, esclareceu-se que contribuíram para significativo resultado pessoal a imagem com excelente resolução postada na mostra do MoMA, associada ao meio digital para rever inúmeras vezes, em ação lúdica. 


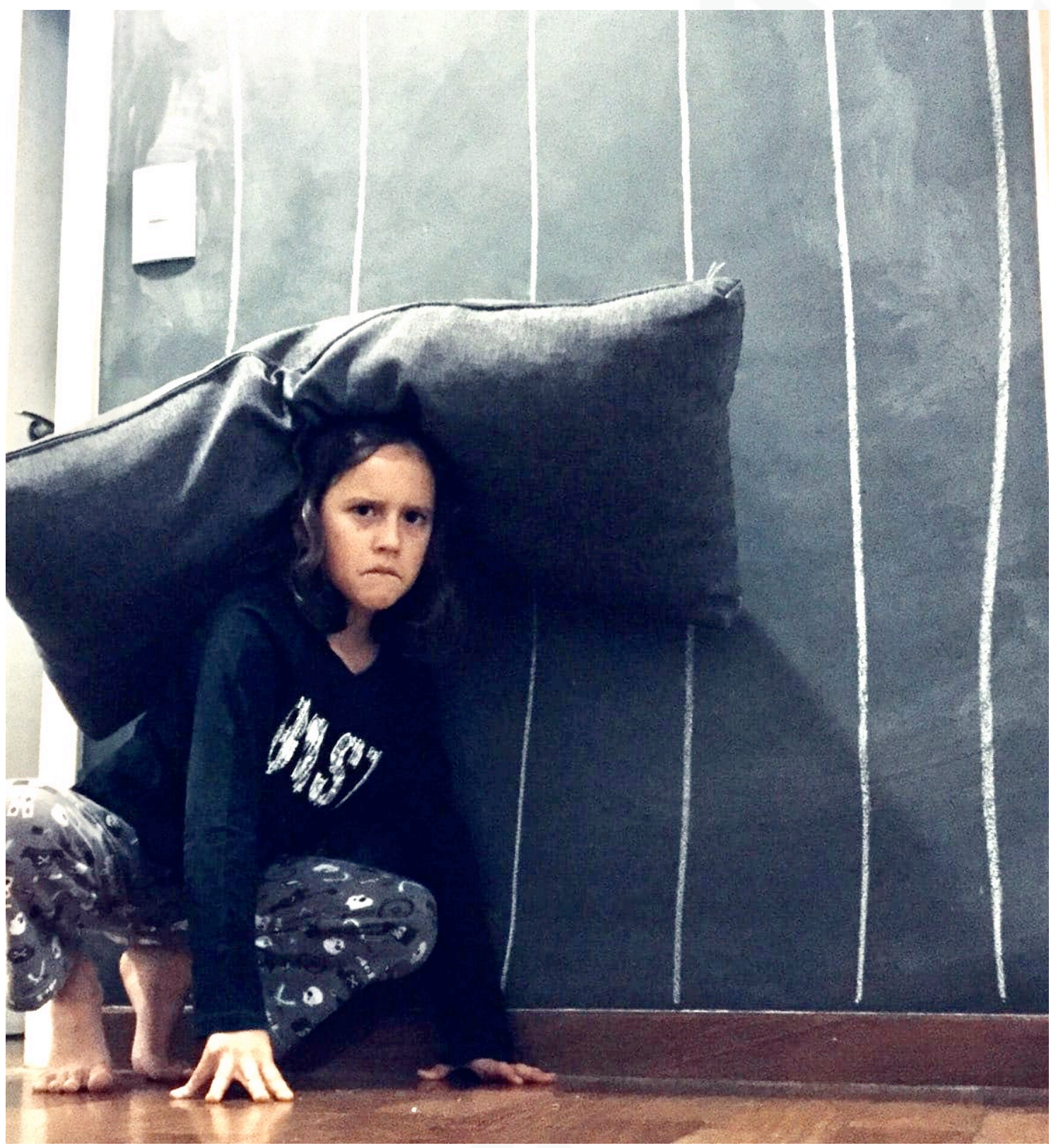

Figura 11: Releitura de "Boi na Floresta" (1928) de Tarsila do Amaral. Autor: Gael Lourenço Sampaio. Fonte: Foto Tadeu Bastos Sampaio.

As criações inventivas estabelecem a face menos trágica da Covid-19, em particular, na reinvenção da prática museal, desde aquela institucional, de serviço, atendimento especializado, sanitarismo, até da sua própria função básica, em candente discussão no ICOM. Dado excepcional foi a união destes com variados segmentos societários 
para acudir populações em seu redor. Entre $\operatorname{tantos}{ }^{30}$, grifos realizações do Museu da Maré/RJ ${ }^{31}$. Fundamenta-se na condição de museu-comunidade, cujos organizadores emergem dela e falam em primeira pessoa do singular, embasados na museologia social $\left.\right|^{32}$. Além de acervo de moradores, desde o início dedicou-se a se envolver com as demandas essenciais, no território em que se situam, diferencial a ser avivado, pela força do desempenho, ao salvar vidas.

Moradores esquecidos de política pública foram alvo de desempenhos compartilhados na pandemia e o Museu da Maré ampliou sua esfera com campanhas em redes sociais, alertas oportunos - "Fique em casa se puder" e encontros virtuais. Como se informou, uniu-se a outros, na Frente de Mobilização da Maré ${ }^{33}$, ampliou a parceria com a Fiocruz, privilegiando preservar vidas. Centralizou-se nele a iniciativa de inúmeras doações em cestas básicas e kits de higiene, como se divulgou, cabendo a este encaminhar aos parceiros, dada a relação por ele estabelecida, algo inédito entre as atividades anteriores. Surgiram também variadas iniciativas para contar a história desta pandemia, em ações tecnológicas, a citar "Inumeráveis", memorial dedicado à história de cada uma das vítimas do Coronavírus no Brasil, colhendo histórias de vida, iniciativa do artista Edson Pavoni e equipe; também no "Museu do

\footnotetext{
${ }^{30}$ Acrescente-se no Rio de Janeiro: o Ecomuseu de Sepetiba, Museu das Remoções, na Vila Autódromo, Museu Casa do Bumba em Movimento, na Vila Catiri, o MUF/ Museu de Favela, em Bangu; em Belo Horizonte: o Ponto de Memória Museu do Taquaril, o MUQUIFU Museu dos Quilombos e Favelas Urbanas, no Bairro Santo Antônio.

${ }^{31}$ Em 1989, grupo de jovens resolveu criar a TV Maré como veículo para gravar experiências, inquietações e cotidiano, gerando acervo, seguido em 1997 pela criação da Rede Maré para salvaguardar memória e histórias da comunidade, junto ao CEASM (Centro de Ações Solidárias da Maré). No ano seguinte associaram-se ao Museu da Vida da Casa de Oswaldo Cruz para formação de monitores. Etapa subsequente foi a criação de Museu da Maré em 2006, por ação de jovens da comunidade, voltado a rever os clichês da favela.

${ }^{32}$ A Declaração de Caracas (ICOM/1992) trazia já uma série de aspectos sobre desafios de novos objetos e ações museais, aspectos agora revisitados de forma participativa e em processo. Entre os tópicos, encontravam-se "Recomendações" acerca da ampliação do conceito de patrimônio, museu e processo de atuação, entre elas cito: Que os museus "[...] desenvolvam investigações mais profundas e amplas sobre a comunidade $[. .] ;.[. .$.$] valorizem o entorno e sua contextualização [\ldots] ;[\ldots]$ organizem estratégias que permitam desenvolver a participação da comunidade $[\ldots] ;[\ldots]$ incentivem a investigação [...]para o reconhecimento de seus próprios valores".

${ }^{33}$ Entre estes se encontram Levante Popular da Juventude, Movimento dos Trabalhadores Rurais Sem Terra (MST), Movimento dos Atingidos por Barragens (MAB), Movimento dos Pequenos Agricultores (MPA), Movimento dos Trabalhadores e Trabalhadoras por Direitos (MTD), Consulta Popular e Agenda Jovem da Fiocruz
} 
Isolamento Brasileiro", no Instagram (@museudoisolamento) de Luíza Lorenzi Adas, no início de maio.

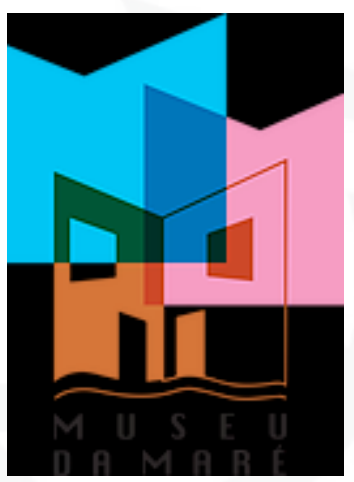

Figura 11: Logotipo do Museu da Maré. Fonte: Site do Museu da Maré.

Sem poder ganhar as ruas para protestos e diante da ausência de políticas de Estado e Governo, explicações críveis, soluções factíveis sobre combate do Coronavírus e com edifícios abarrotados, iniciaram-se manifestações de protestos, em telas mais rugosas, entrando em cena empenas de edifícios pelo país, que revisitaram formas expressivas anteriores online. Cito, entre estas, o@vivajk, atuante desde o ano passado (2019), no início voltado a projetar no edifício de mesmo nome, criado por Oscar Niemeyer (1952), com muitos moradores e desejosos de ressaltar que lá também há inúmeras histórias, além daquela sobre o arquiteto. A evidência de se manter em casa ampliou as mensagens e o alcance.

Outro com astúcia, \#projetemos, no Instagram, no início acompanhou "panelaços" contra falas do presidente, que minimizavam a pandemia, mas também para alertar contra o perigo ${ }^{34}$. Como se veiculou a 28 de março de 2020, na revista Veja, estes ataques viralizaram e foram noticiadas no londrino The Economist. Nesta data contava então como 100 adesões em 5 Estados e no Distrito Federal. Passado um

\footnotetext{
${ }^{34}$ Assinale-se: "Serviços Públicos Salvam Vidas", "Defenda o SUS", "Vai dar Tudo Certo", "Ficar Em Casa É o Remédio Mais Barato Contra o Coronavírus" e "Todo Mundo Deveria Ter o Direito de Ficar em Quarentena" e gratidão aos que não podem ficar em casa, para que a maioria tenha condições, além dos profissionais de saúde.
} 
mês, os criadores ${ }^{35}$ anunciaram que o número havia dobrado ${ }^{36}$. Lançouse, \#ArteSalva a 28 de maio, que projeta imagens e vídeos em prédios de Belo Horizonte, São Paulo, Rio de Janeiro, Recife e Porto Alegre.
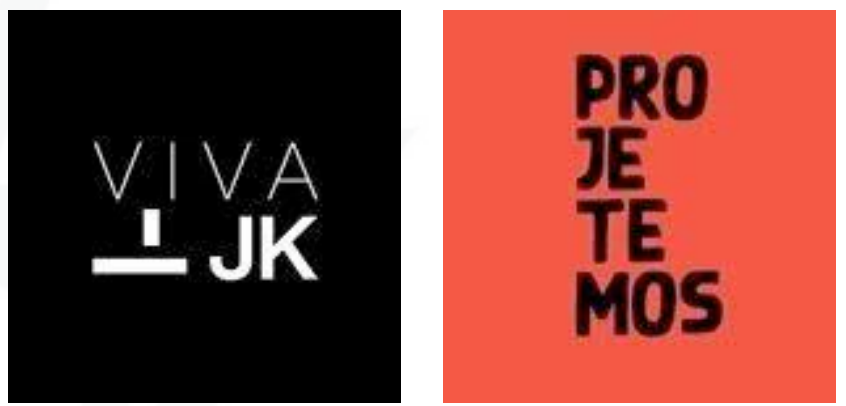

Figura 12 e 13 - Logotipos "Viva JK" e Projetemos". Fonte: Site dos citados

\section{CONSIDERAÇÕES FINAIS}

Uma vez mais, durante a pandemia de Covid-19, a hiperexposição de imagens evidencia sentimentos latentes por palavras, formas e espaços. Enfrentar situações extremas, com criação de conteúdos como os aqui analisados ocorreu em escala global, porquanto, muitos se encontram com o mesmo problema. Assim, ampliar e estabelecer conexão entre pessoas, com trocas por meio de imagens, nesta pandemia suavizou as inevitáveis dificuldades. Poesia, literatura, música, artes visuais, teatralização funcionaram como disparador, para longe, destes momentos estendidos, soturnos e isolacionistas no próprio habitat. As relações foram mediadas por superfícies diversas, desde aquelas compartilhadas no celular, até as tecnologias de realidade aumentada, em que se integram formas reais a outras, por câmeras estendendo e expandindo o campo do olhar e criar. Restam dúvidas sobre o póspandemia, que se procurou formular nesta reflexão, mais do que certezas.

\footnotetext{
${ }^{35}$ São eles, o produtor audiovisual VJ (vídeo jóquei) Felipe Spencer/SP e a cientista política Bruna Rosa/DF.

${ }^{36}$ Como se anunciou em veículos digitais locais, em Recife a iniciativa se deveu a Mozart Santos, em Belo Horizonte a Leandro Miranda.
} 
O nomeado Novo Normal dará continuidade à prática de imagens como parte seminal no dia a dia? Continuarão online ações em áreas como educação, saúde, ativismo, crítica, crônica, deslocamento imaginário para tempos passados? Permanecerão rostos e hábitos, antes ignorados, que na pandemia emergiram em trajes, expressão corporal, máscaras e higienismo exacerbado? Atividades em presença com obras museais incorporarão releituras com humor, jogo, criação e sátira e interpretações diversas? A preocupação com distintos segmentos se evidenciará em mensagens projetadas, lambe-lambe em paredes, grafites, canções com mensagens de imediato entendidas à distância, capazes de unir pessoas sós, desconhecidos, vizinhos, amigos e parentes, acenando com fraternidade incomum, como se viu na Covid-19? Preconceito etário e protecionismo extremo finalmente terminará?

Alguns museus durante a pandemia reavivaram o veio midiático, ainda restringindose a difundir seus ícones, ou como se dizia, seu conjunto de obra-prima. O museuespetáculo continuará na escala antes assumida? Inimaginável! Teria sensibilidade para ao menos se avizinhar e ampliar postura com acento crítico, antes elaborada por artistas? Como aqui se reitera, a expressão sensível pode antever e, não apenas, refletir o momento histórico, como veicularam deterministas e positivistas Oitocentistas. A solenidade ante obras museicas deu lugar ao deboche e encená-las para crianças e adolescentes acarretou observação particularizada, adaptação de superfície, mantendo-se o cromatismo, a posição das formas e minúcias, em geral despercebidos, que merecem incentivo.

O desafio aguçou empenho, incentivados por professores e familiares, em casa. Uniram-se dimensões pouco exploradas em visita presencial a museu, quando não se pode tocar, aproximar e realizar fruição táctil. Na pandemia, superou-se a mania de se tentar reduzir obras a palavras explicativas, com textos e etiquetas, inexistindo o enfadonho exercício, comum em visita de crianças, pedindo que desenhem o que mais gostou. A visita habitual pede silêncio, modo contemplativo, distante e passivo. Ingerir alimentos como em casa, ou gritar, nem pensar. Com a vivência das obras e aproximação ao espaço doméstico despontaram encontros mais lúdicos, ativos, próximos, desafiadores, ativaram tactilidade e experiência, como se fossem obra viva. 
Nessa disparidade de situações e reações, muitas telas de celular, iPad, computador, notebook e mesmo de TV desempenharam o papel de entre-espaço, a ligar coleções museais conhecidas, banalizadas ou não, ao espectador, em vizinhança e escala ignorada. A rotina para se adaptar a fatos como perdas e separação não ocorreu apenas em museus, mas, principalmente nas pessoas em várias faixas etárias. A condição de isolados, gerou atração pela imagem, perseguição ao diálogo e envio de mensagens e informes sobre a doença, vida e morte. Sem falar em Fake News sobre a pandemia, replicadas sem cuidado para aferir em outras fontes. Pior ante a interdição de trocas presenciais, exilados no ambiente habitado, a dificuldade maior foi o desaparecimento de tantas vidas e a imensa população destituída da condição, de ficar em casa e higiene essencial, não por escolha, ignorada em pronunciamentos oficiais.

O espaço da rua ficou reservado para uma série de atividades profissionais, que não se pode realizar à distância, escancarando desnível social e desnudando o conflito entre público versus privado, para os que exercem função remota em suas casas. Quem tem direito a ficar em casa, para as levas de cidadãos em condição de rua? Agora rostos vazados por máscaras dissimulam expressões, vive-se espécie de obsessão por encontros em mídia eletrônica e pioneirismo em passar mensagens trágicas, idolatria por purificação, quase religiosa, de novo o pêndulo varia entre fascinação e repulsa por imagem pública ao vivo ou online, a merecer sutis soluções na edição do ambiente doméstico.

O que se perdeu de substantivo ao ser interditado ao público, por medidas sanitaristas? Claro está que os maiores défices reitero com pesar são perdas humanas, cortes laborais e, também, ausência de planos para cultura. Por outra face, abalou-se, em cascata, apoio financeiro, prática de distinção, prestígio e lucro de poucos. Ao se considerar que o urbano constitui verdadeiro museu, com invisíveis, edificações, praças e monumentos constatam-se esforços em continuidade para garantir sobrevivência humana, sentimentos e funções perdidas. Desejo que se continue a aprofundar as relações em trocas entre pessoas, sócio-políticas sensíveis com trabalho, paisagem, cidade e formas dispostas à visão, um dos sentidos essenciais, a nos humanizar. Assim, pode-se sonhar com um futuro melhor, embora com novas pandemias, e esta situação, por hora, vai passar! Ciça, Primavera 2020. 


\section{BIBLIOGRAFIA CITADA}

AMARAL, Aracy Abreu. Correspondência Mário de Andrade \& Tarsila do Amaral. São Paulo: EDUSP/IEB/USP; 2001. -Tarsila cronista. São Paulo: EDUSP; 2001. arsila sua obra e seu tempo. São Paulo: Perspectiva/EDUSP; 1975.

BENJAMIN, Walter. A obra de arte na época de sua reprodutibilidade técnica. São Paulo: Abril Cultural; 1975.

HESÍODO. Teogonia: a origem dos deuses. São Paulo: Iluminaresç; 1995.

HOCKNEY, David. O conhecimento secreto: redescobrindo as técnicas perdidas dos grandes mestres. Trad. José Marcos Macedo. São Paulo: Cosac \& Naify;1996.

LOURENÇO, Maria Cecília França. Almeida Júnior: um criador de imaginário. São Paulo Pinacoteca do Estado; 2007.

MONDZAIN, Marie-José. A imagem pode matar? Lisboa, Vega; 2009 [2002].

STAROBINSKI, Jean. A invenção da liberdade 1700-1789. São Paulo: Unesp; 1994.

\section{Fontes eletrônicas e sites}

ASSIS, Tatiana de. Quem está por trás de meme de Bolsonaro visto em panelaços. Disponível em: https://vejasp.abril.com.br/blog/arte-ao-redor/bolsonaromascara-projecoes-artistas-vjs/. Acesso em: 30 mar. 2020.

BEIGUELMAN, Giselle. Coronavida: A cultura do coronavírus: prólogo do confinamento. $O$ espaço público é a primeira vítima fatal. Revista SelecT. Disponivel em: https://www.select.art.br/coronavida/. Acesso: em 15 abr. 2020.

Coronanavida: o pós-pandêmico é agora. São Paulo: Escola da Cidade, 2020. Disponível em: https://n-1edicoes.org/086/. Acesso em: 20 set. 2020.

CAPA do livro editado na exposição //conoclash. Disponível em: https://zkm.de/en/thezkm/ Acesso em: 17.09.2020.

CINDY Sherman. Disponível em: http://www.cindysherman.com/. Acesso em: 12 set. 2020.

DECLARAÇÃO de Caracas 1992. Disponível em: https://edisciplinas.usp.br/pluginfile.php/3832715/mod/ . Acesso em: 2 jun. 2020.

ICOM Brasil "Recomendações do ICOM Brasil em relação à COVID 19". Disponível em: https://www.icom.org.br/. Acesso em: 02 maio 2020. 
INUMERÁVEIS. Disponível em: https://inumeraveis.com.br/projetemos/. Acesso em: 22 jun.2020.

ERA VIRTUAL. Disponível em: http://eravirtual.org/. Acesso em: 13 abr. 2020.

HOCKNEY, David. Secret Knowledge part 1 Disponível em:

https://www.youtube.com/watch?v=wpG-ZwnNNaA/. Acesso em: 19.09.2020.

GOOGLE Arts \& Culture. Disponível em: https://artsandculture.google.com/. Acesso em: 12 mar. 2020.

BALLESTER, José Manuel. Disponível em: https://www.josemanuelballester.com/. Acesso em: 29 mar. 2020.

EILLY, Maura. “Carolee Schneemann: 'Em que Se Transformou a Pintura?'”. eRevista Performatus, Inhumas, ano 4, n. 16, jul. 2016. ISSN: 2316-8102. Disponível em: https://performatus.com.br/traducoes/carolee-schneemann-pintura/. Acesso em: 13 set. 2020.

LATOUR, Bruno. "O que é Iconoclash? Ou, há um mundo além das guerras de imagem? Revista Horizontes Antropológicos, Porto Alegre, ano 14, n. 29, p. 111-150, jan./jun. 2008. Disponível em: http://www.brunolatour.fr/sites/default/files/downloads/84-ICONOCLASH-POR.pdf/. Acesso em: 4 ago. 2010.

LOGOTIPO Coletivo Viva JK/ BH. Disponível em: https://www.instagram.com/vivajk/ \#projetemos. Disponível em: https://www.instagram.com/projetemos/.Acesso em 10 de maio 2020

Museu da Maré Disponível em: https://www.museudamare.org/. Acesso em: 19 set. 2020.

MAURITSHUIS Museum Disponível em: https://www.mauritshuis.nl/en/explore/restoration-and-research/girl-in-thespotlight/. Acesso em: 20 set. 2020.

MAURITSHUIS Museum. Renovação do edifício. Disponível em: https://www.mauritshuis.nl/en/discover/mauritshuis/the-renovation/. Acesso em: 20 set. 2020.

MUSEUS anunciam demissões. Disponível em: https://vejasp.abril.com.br/blog/arteao-redor/museus-e-teatros-demissoes-suspensao-contratos/. Acesso em: 4 de maio 2020.

MUSEU da Maré. Disponível em: https://www.museudamare.org/. Acesso em: 12 de jun. 2020.

MUSEU do Isolamento. Disponível em: https://www.toopics.com/tag/museudoisolamento/. Acesso em: 12 abr. 2020. 
PAINEL na entrada da exposição no MoMA. Disponível em:

https://www.moma.org/calendar/exhibitions/3871/ Acesso em 21 ser.2020

PESSOA, Fernando. Oscila o incensório antigo. Disponível em: https://www.escritas.org/pt//1088/oscila-o-incensorio-antigo/. Acesso em: 16 set. 2020.

TUSSEN Kunst \& Quarantaine. Disponível em: https://www.instagram.com/tussenkunstenquarantaine/?hl=pt-br/. Acesso em: 21 mar. 2020.

UNESCO. Disponível em: http://whc.unesco.org/uploads/nominations/208rev.pdf/. Acesso em: 24 ago. 2020. 